\title{
The methodology of kineto-stratigraphy as applied to glacial geology
}

\author{
ASGER BERTHELSEN
}

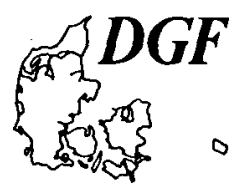

Berthelsen, A.: The methodology of kineto-stratigraphy as applied to glacial geology. Bull. geol. Soc. Denmark, vol. 27, Special Issue, :pp. 25-38, Copenhagen, July 30th 1978. https://doi.org/10.37570/bgsd-1978-SI-04

\begin{abstract}
Studies of contorted drift sequence in southeastern Denmark have resulted in a fusion of the working methods and principles of glacial-tectonics and lithostratigraphy and in the formulation of a new type of stratigraphy, kineto-stratigraphy, where main emphasis is placed on the study of the directional elements that reflect the movement patterns (kinetics) of former ice sheets. Through studies of principal localities, where deposits and deformation from more than one glacial advance are found, regional kinetostratigraphic drift units are established, and local glacial deposits are classified accordingly. The relative significance of the various directional elements is discussed, and a brief outline of the new Weichselian kineto-stratigraphy of southeastern Denmark is given.
\end{abstract}

Asger Berthelsen, Institute of General Geology, Ostervoldgade 10, DK-1350 Copenhagen $K$. February 28th, 1978.

In 1969 the author and his co-workers initiated a reinvestigation of Weichselian drift successions in Denmark with the aim to establish a detailed till stratigraphy. The earlier literature dealing with this problem was reviewed by Berthelsen (1973) who also introduced the concept of kinetostratigraphy in connection with a presentation of some preliminary results. A kineto-stratigraphy drift unit (fig. 1) was defined as the sedimentary unit deposited by an ice sheet or stream possessing a characteristic pattern and direction of movement (opt. cit. p. 23), and it was pointed out how the study of glacial striae on solid bedrock and boulder pavements, till-fabric, and the structural analysis of glacially induced deformations may help to distinguish between drift units deposited by successive glacial advances coming from different directions.

Since 1973, this line of approach has been tested in practise by a number of researchers working on the Weichselian glacial deposits of southeastern Denmark (Berthelsen 1974, 1975 b, Berthelsen, Petersen \& Konradi 1977, Frederiksen 1976, Houmark-Nielsen 1976 a and b, Jacobsen 1976, Jensen 1977, Petersen \& Buch 1974, Petersen 1978, Rasmussen 1975, Selsing 1977, Sjørring 1974, 1977 a and b, 1978). Against this background, it may be relevant to discuss some more specifically the theoretical and practical aspects of kinetostratigraphy, in the hope that this may prove of use to students of other complex glacial regions. More detailed accounts of examples of local Danish till stratigraphy can be found in Petersen (1978) and Sjørring (1978).

Although early description of the Weichselian glacial deposits in Denmark include some pertinent descriptions of 'dislocated cliffs' where the Quaternary strata are strongly disturbed (see for example Jessen 1930 and 1931), the working methods used in glacial-tectonic studies were first

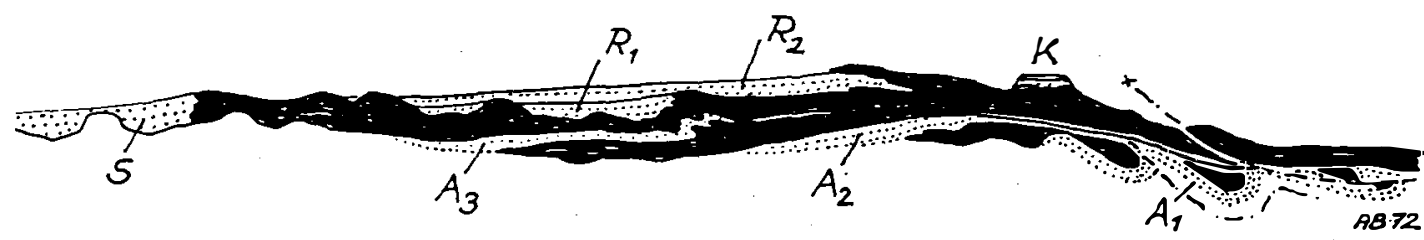

Fig. 1. Diagrammatic sketch of a kineto-stratigraphic unit. The vertical scale is exaggerated, the length of the section could be from $10 \mathrm{~km}$ to over $250 \mathrm{~km}$. Till deposits are shown in black.
Stratified drift is dotted, A: from progressive halts, S: from maximal advance, $R$ : from readvances during general recession, $K$ : kame deposits. From Berthelsen (1973). 

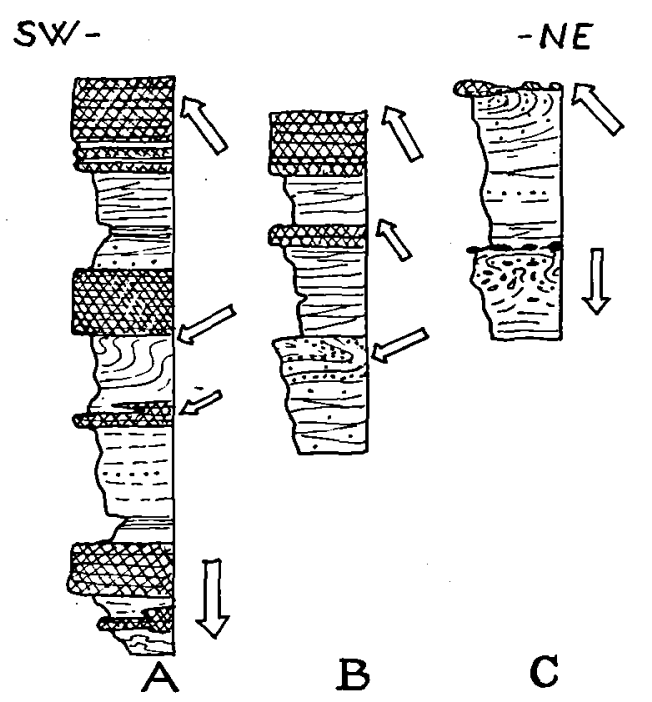

Fig. 2. Diagram illustrating kineto-stratigraphic classification. To the left the stratigraphic columns from three localities, $A, B$, and $C$, that are arranged along a $S W-N E$ line. Directional elements measured from glacial-tectonic deformations are indicated with the north-arrow pointing upwards along the columns. To the right the same deposits are grouped into kineto-stratigraphic drift units: $I, I I$, and III.

dealt with by Gry (1940), and until recently it has been customary in Denmark to base the division of the glacial deposits on studies of morphological features and the lithology of the mapped surficial deposits, counting of indicator boulders as well as 'stone counts' have been used as auxilary methods. The concise papers of Andersen (1950, 1957) mark an exeption to this classic approach, since they contain description of detailed stratigraphic relations of the sub-surface deposits.

The application in more recent years of heavy machinery in gravel digging has resulted in the production of many impressive inland exposures, and often extremely complicated stratigraphic relations have been disclosed in the interior of the glacial landcape. Renewed inspection of coastal sections has also revealed that contorted drift deposits are of much wider distribution than hitherto belived.

It was this situation where normal stratigraphic relations appear to be the exception rather than the rule, that confronted us when the abovementioned reinvestigation was started. It soon became obvious that the classic stratigraphic methods did not satisfy the complex set-up found in most exposures. To use a formal lithostrati-

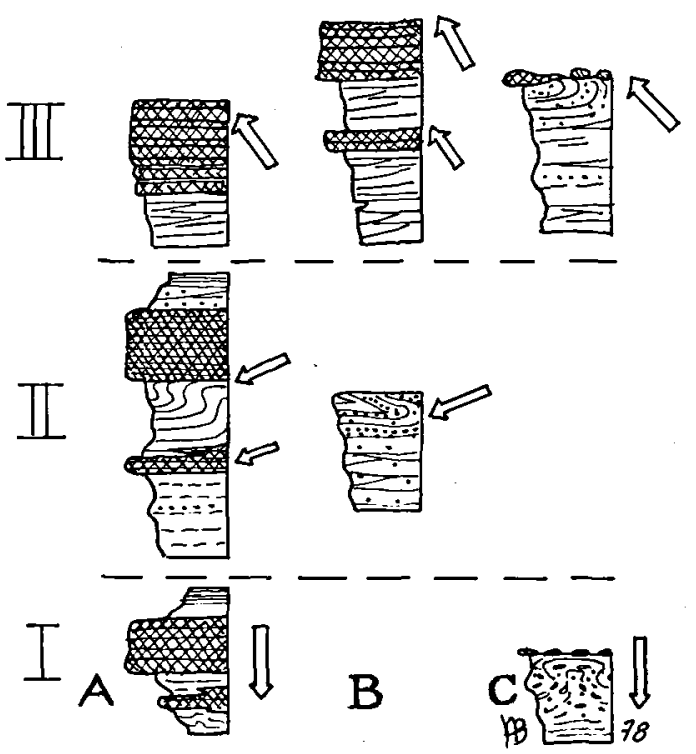

graphic classification in this situation would only add confusion to the problem by creating a useless jungle of formation names. How could sedimentary units be correlated, when the distance between good exposures surpasses their areal extension, and when the latter in some cases may be less than the amplitude of the glacially induced deformations?

The intricate stratigraphic relations presented by Danish glacial deposits are, however, in no way more complex than those met with in many highly deformed crystalline terrains, and the idea soon came to mind that the methods and principles developed in the study of complex orogenic features could also be used to decipher the complex glacial deposits of exogene origin.

Work along this line resulted in the formulation of a new type of stratigraphy, kineto-stratigraphy, which differs from generally accepted types of stratigraphy in that glacially induced deformational structures are studied in a stratigraphic context, and the individual sedimentary units are then grouped into kineto-stratigrapical units according to their directional elements (fig 2). Hence, kineto-stratigraphy is only stratigraphy in the sense that its ultimate goal is the establish- 
ment of a stratigraphic colum. It does not take its immediate starting point in the study of the strata as such.

\section{A comparison with orogenic structures}

As a further illustration of these complexities a comparison with 'event stratigraphy' as practised in deep orogenic zones will be given. In many crystalline terrains, a sequence of orogenic deformations can be deciphered, and successive deformational episodes are often recognised from geometrical criteria. Stratiform rock units are folded, refolded, refolded again, and new schistosities are superimposed on older ones. In the geological literature that deals with the deformational chronology of multi-deformed basement complexes, it is customary to speak of $F_{1}, F_{2}, \ldots$ $F_{x}$ phases, and the rocks that suffered from the successive episodes of deformation are spoken of as $F_{1}$-deformed, $F_{2}$-deformed rocks etc., even if the rocks that contain the $F_{1} \ldots F_{x}$ structures are often classified and mapped according to what is belived to be their primary lithology.

This type of approach in reality represents a combination of lithostratigraphic and kinetostratigraphic methods, but because the structural units ( $\mathrm{F}_{2}$-deformed rocks etc.) are geometrical units comprising rocks of different age and origin, the expression structural chronology, and not kineto-stratigraphy, is used.

In a multi-glaciated region where contorted drift successions occur abundantly, a structural chronology may also be worked out through the study of the deformations caused by the successive glaciations. In this case, however, the events - the glaciations - caused not only deformation but also deposition of sediments, i.e., till, icecontact sediments and stratified drift. It is this particular situation, where both deformation and genetically related strata become involved in the study, that justifies the use of the term kinetostratigraphy.

The kineto-stratigraphic approach has made structural analysis of glacially induced deformation as important a stratigraphic tool as the study of glacial striae is in other regions with different geological situations (Lundqvist 1975, Königsson \& Linde 1977). In this connection, the interesting paper by Hirvas, Kujansuu \& Tynni (1976) on the flow stages of the pre- and post-Eemian glaciations in northern Finland also deserves mention.

Returning to basement tectonics, in the structurally most complex basement regions it is often impossible to resolve the whole part of a prolonged tectonic evolution, because the younger deformations have been accompained by such intense shearing and penetrative movement that not only all primary features of the rocks involved, but also the deformational structures that date from the oldest events, have been effaced beyound recognition. Under such conditions it is not advisable to use a formal lithostratigraphic nomenclature for the mapped stratiform units, because such a procedure would imply the applicability of Steno's Law of Superposition, which refers to strata superposed by other strata, and not to deformational structures superimposed on other deformational structures (Berthelsen 1975 a: 3). In such cases, a subdivision into 'neutral' lithostructural units (Berthelsen 1960: 14, Berthelsen \& Henriksen 1975: 23) is to be recommended since by doing so, no definite attitude is taken as to the origin of the lithological layering or stratiform shape of the units.

The expression 'lithostructural unit' has recently been introduced in glacial stratigraphy by Banham (1977) in connection with a description of how the upper part of pre-existing strata can become so thoroughly changed by glacially induced penetrative movements that it must be considered as belonging structurally to the overlying lodgement till (Banham 1977, fig. 2). The present author would consider such an intensly reworked zone as simply the lowermost part of the lodgement till and as belonging to the same kinetostratigraphic unit as Banham's lodgement till, and consequently sees no particular need to classify glacial deposits into lithostructural units. The concept of lithostructural units was introduced in order to describe stratiform hardrock units of much more obscure origin (Berthelsen 1960: 14). But apart from this disagreement on nomenclature, the present author fully shares Banham's (1977) view as to where the lower limit of a kinetostratigraphic unit should be placed: it should be placed at the lower limit of the sediments that were deposited in connection with the advance and retreat of a given ice sheet. "Deposition" in this context comprises glaciofluvial sedimentation and glacial deposition; the latter includes intense 
glacial-tectonic reworking that changes subjacent strata into "new" sediments. This means that the lower border of a kineto-stratigraphic unit coincides with lithologic borders (the influence of possible hiati being disregarded), and that the unit is not defined as all sediments that are kinetically influenced by the given advance. The kinetic influence of a glacial advance diminishes downwards in a section; sometimes it is limited to the sediments of the correspondng kineto-stratigraphic unit, in other cases it reaches deeper and affects subjacent strata, older kineto-stratigraphic units or pre-Quaternary sediments.

\section{Dominal and extra-dominal deformation}

In order to simplify the descriptions of glacialtectonic structures and stratigraphic relations, it is useful to distinguish between 1) deformational structures that occur within the sediments belonging to a given kineto-stratigraphic unit, and 2) those that influence older strata that are subjacent to this unit. Deformation occurring in its own kineto-stratigraphic domain, will here be called domainal, while a deformation is said to be extra-domainal where it affects subjacent strata, fig. 3.

Domainal deformation may be either syngenetic, as in lodgement tills, or cogenetic where it influences already deposited strata, e.g. stratified drift, that form part of the kineto-stratigraphic unit, characterised by the deformation in question. Extra-domainal deformations could be called epigenetic because they are genetically unrelated to the deposition of the strata affected, and were imposed later.

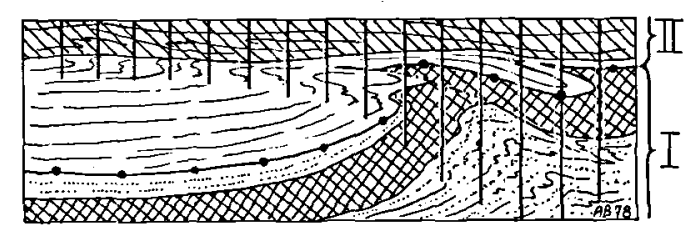

Fig. 3. Diagram illustrating domainal and extradomainal deformation related to an upper kineto-stratigraphic unit (II). To the left, the domainal deformation does not reach down to the lower limit of unit II, but to the right subjacent strata (of unit I) become affected by extra domainal deformation (related. to the deposition of unit II).
Extra-domainal deformation related to domainal deformation in an overlying kineto-stratigraphic unit, may in some cases affect already deformed subjacent strata, so contorted drift may show many kinds of superimposed structures: Multiple folding, thrust folds, folded thrusts, thrust-cut thrusts, and transposed foliation or schistosity. The amplitude of such superimposed structures may reach several tens of metres and even exceed one hundred metres, so both good exposures and analytical skill are needed in order to decipher them (fig. 4).

As pointed out by Banham (1977), a logdement till in statu nascendi and in direct contact with subjacent strata may be accompanied by such an intense shearing in the upper part of these strata that this upper part becomes forcefully incorporated in, and made an integral part of the till under formation. In this situation, extra-domainal deformation gradually changes into domainal as in course of time it becomes penetrative and intense, in which case the position of the boundary between the kineto-stratigraphic unit and the subjacent strata does not remain constant, but moves downwards. One could speak of a descending front of penetrative deformation.

If, on the other hand, a thick sequence of genetically related stratified drift underlies the lodgement till during its formation, the domainal deformation may be absorbed wtihin this sequence and may die out before the lower boundary of the kineto-stratigraphic unit is reached (fig. 4). However, even when this is seen to be the case in shallow exposures, the possibility that more deeplying extra-domainal deformation has taken place cannot be excluded. Displacement of formerly permafrozen floes or thrust sheets along deep (10-100 m) subhorizontal thrust planes is not rare in the Danish Quaternary. Since the stratigraphic relations within the individual slices may be completely undisturbed, such structures can easily escape recognition, unless extraordinarily deep erosional sections have been cut. If distinctly recognisable interglacial or pre-Quaternary deposits are involved in the thrusting, the presence of such structures may be inferred from information supplied by drilling and wells (Stockmarr 1978).

The situation mentioned illustrates how important it is to distinguish between domainal and extra-domainal deformation when deducing mo- 


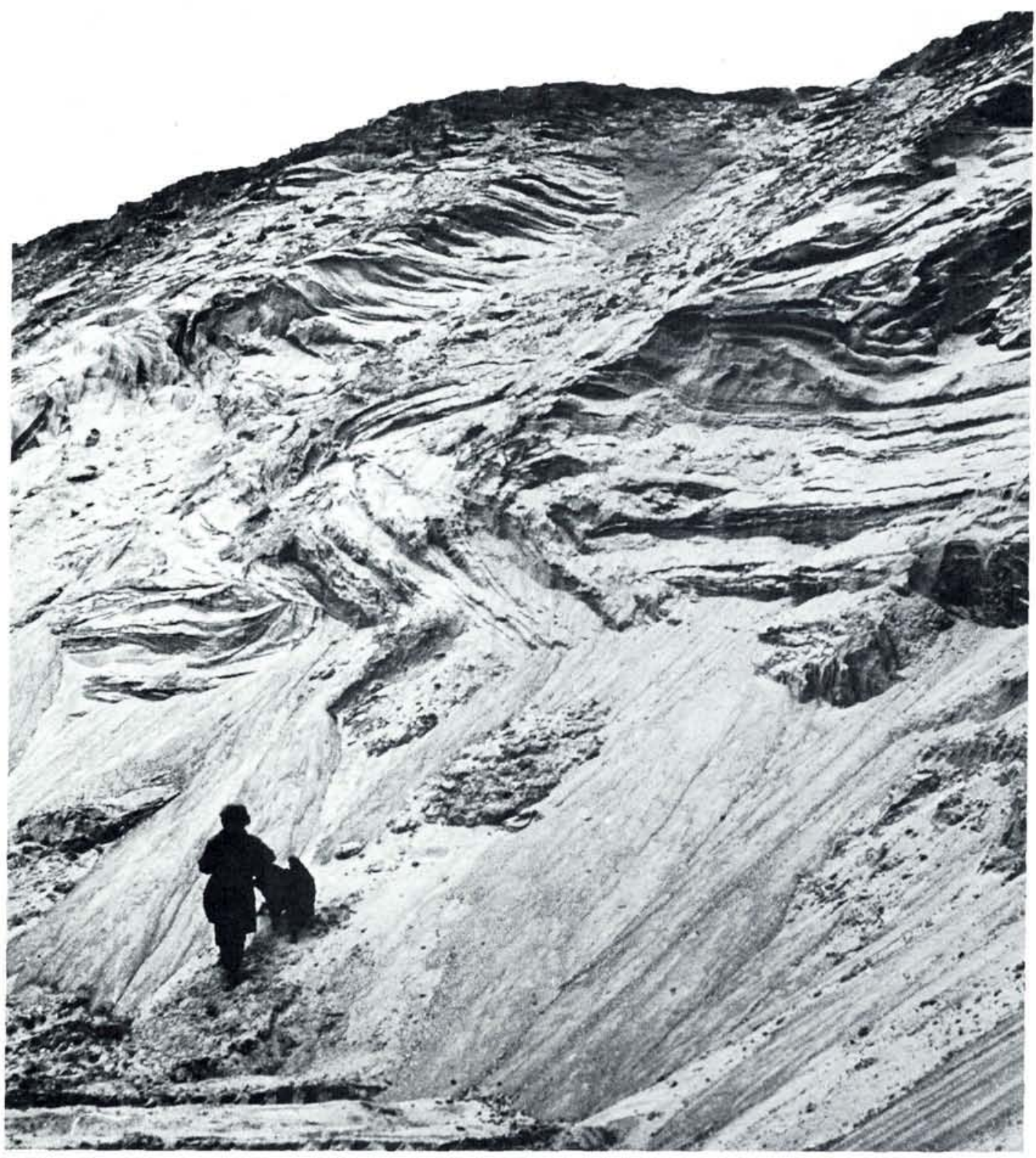

Fig. 4. Domainal deformation of sandur deposits laid down in front of the advancing NE-ice, Botterup gravel pit, NE-Sjaelland. In the section shown the overlying till has been removed. Foto: $A . B$.

vement patterns from these structures and establishing their correct succession. Exposures where two or more kineto-stratigraphic drift units are found and where all units show only domainal deformation are therefore of prime importance in all kineto-stratigraphic work.
Evaluation of the kineto-stratigraphic method

The kineto-stratigraphic principle, as defined by Berthelsen (1975 b: 28), claims that the deposits laid down by successive glaciations can be distin- 
guished by means of the kinetic patterns deduced from the domainal and extra-domainal deformation related to each glaciation, and that the glacial deposits should be correlated according to their directional elements, i.e. all available evidence of direction of movement or glacial flow. This principle brings a new, complex line of thinking into glacial geology, since it demands combined structural and stratigraphical studies, and since it compels one to operate with multiple working hypotheses and to distinguish between degrees of conclusiveness.

In compensation, it makes it possible to collect indirect stratigraphic evidence from 'empty' localities where the only testimony of the coming and going of a former ice sheet consists of extradomainal disturbances. Owing to common occurrence of local erosional hiati through removal of till beds, combined with the often restricted extension of stratified drifts units, such indirect stratigraphic information is very valuable when correlation has to be attempted in areas with such gaps, fig. 5.

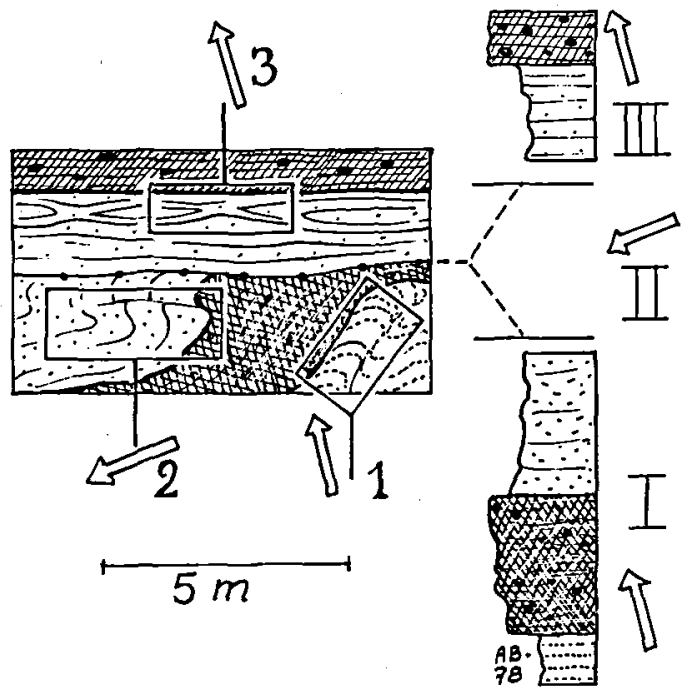

Fig. 5. Diagrammatic sketch illustrating the use of an 'empty' locality. In the profile (left) there are deposits from only two kineto-stratigraphic units (below and above the unconformity), but due to the extra-domainal deformation (2) related to the 'missing' unit, the former existence of the latter can be inferred (unit II in the column to the right).

Like many other geological methods, the kinetostratigraphic one is empirical. It must be tested regionally before it can applied locally - and the regional testing is done by fitting together local results! It is something of a consolation that a similar built-in uncertainity characterises most classic and esteemed methods in geology.

The testing of the applicability of the methods in a given region such as Denmark should include checks as to whether or not certain fundamental requirements are fulfilled. One important basic assumption is that the movement pattern of each of the former ice sheets really was so regular and continuous over a reasonably large region that it can be reconstructed satisfactorily by studying the limited number of available exposures. The pattern of movement traces related to the last ice sheet covering a given region offers a particularly good opportunity for checking this assumption, when the stratigraphic position of the deposits and dislocations left by the last ice sheet can be ascertained by several other methods than kineto-stratigraphy. In Denmark, such checks have been made in deposits related to both the second last and the last Weichselian ice sheet, since the latter only partially overlapped the extension of the former, fig. 11.

It is also important to find out if the individual regular kinetic patterns of successive or separated ice sheets really have different directions of glacial transport. Provenance dependent features of glacial drift deposits should therefore be studied and compared with the information supplied by the directional elements. In Denmark, the Weichselian tills often contain detectable amounts of admixed foraminifera originating frem subjacent Eemian or early to middle Weichselian marine deposits (Feyling-Hansen et al. 1970, Konradi 1976, Knudsen and Feyling-Hansen 1976), and studies of such admixed faunas have yielded valuable checks on correlation (Konradi 1973, Petersen \& Buch 1974, Petersen \& Konradi 1974, Berthelsen et al. 1977, Petersen 1978).

In earlier studies, 'petrographic' methods, such as stone counts and content of indicator boulders, were used in order to deduce the provenance of the glacial deposits. Since the admixture of material from pre-existing (including pre-Eemian) drift units have now been recognized, it is obvious that these methods should be reassessed in the light of the new kineto-stratigraphic results rather than serve as a check for the latter. Holm (1978) recently demonstrated that this also appears to be the case with heavy mineral studies.

Even if the possibility of admixture of pre- 
Eemain fossiliferous interglacial/interstadial marine deposits cannot be entirely excluded, the study of admixed foraminiferal faunas from Eemian to Middle Weichselian deposits is believed to provide a better basis for correlation than 'petrographic' counts.

Another important factor to be kept in mind is that different kineto-stratigraphic units established from work in a restricted area, may turn out to be sub-units that merge into a single more extensive unit when studied in a regional context. This appears to be the case with the two youngest drift units established by Rasmussen (1975) on Hindsholm (NE Fyn, se fig. 11) even if the two units/ sub-units show distinctly different directions of transport on Hindsholm and also on Røsnæs (Berthelsen 1975 b). On Omø some $50 \mathrm{~km}$ southeast of these two localities, i.e. in an 'upstream' direction, Jacobsen (1976) found a much less well expressed difference in the movement directions in the two tills, and classified them as sub-units.

As stressed by Gripp (1973), one and the same

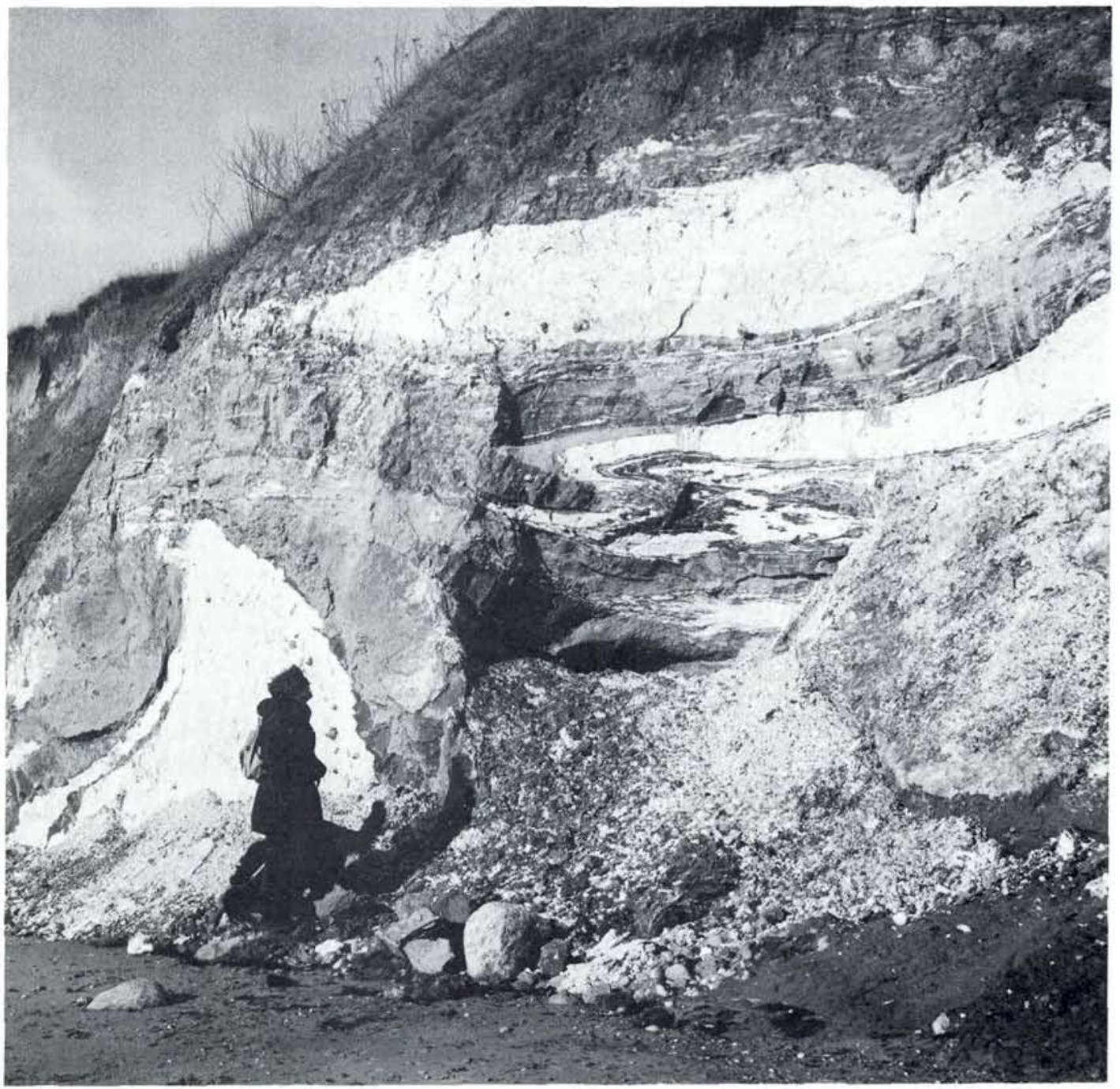

Fig. 6. Glaciodynamic structures in till with floes of chalk that have been partially sheared into thin slices above flat-lying thrusts and later involved in shear-folding. The ice moved from north-north-east to south-soutwest (NE-ice). Hjelm Nakke, south coast of Møn. Foto: A.B. 
glacial advance can show varying directions of movement in its distal and proximal parts, and such directional variations may be registered in the drift sequence. Such complications should be examined at all available localities, and one should investigate whether the splitting up into sub-units records recessions during general advance or readvances during recession. Knowledge about this helps to define the borders of the regional kineto-stratigraphic units, because recession during advance are registered near the base of the unit, and readvances during recession near its top. Under such circumstances, a vertical section may contain several till beds even if it embraces only one kineto-stratigraphic unit, (figs. 1 and 2).

Localities are considered principal when two or more kineto-stratigraphic units are accessible for study in the same exposure. This situation is generally due to strong glacial-tectonic disturbances, fig. 6. The 'dislocated cliffs' well known from earlier descriptions are among the principal localities that have been studied (see e.g. Jessen 1930, and Frederiksen 1976).

In addition to the principal localities, several key areas, each with a relatively high density of good exposures, have been studied in order to check whether or not the kinetic patterns interpreted from observations made at more scattered principal localities can be traced through the intervening areas (Rasmussen 1974, Berthelsen 1975 b, Sjørring 1977 a).

When all these different types of introductory checks have been performed, and a regionally valid kineto-stratigraphic classification that proves to be viable after further checks has been worked out, the kineto-stratigraphic principle can be used in local and more detailed correlation work. Local deposits of restricted distribution can now be correlated according to their directional elements. These are used in much the same way as fossils are used in biostratigraphical correlations.

\section{The directional elements}

The reconstruction of the kinetic patterns of former ice sheets is made through the study of the directional elements in the corresponding kinetostratigraphic drift units and related extra- domainal deformation in subjacent deposits. In such work, it is essential that structures formed under the influence of an active glacier can be distinguished from those formed after the movements ceased and the ice became inactive, dead. Lavrushin (1971) named the former glaciodynamic structures (fig. 6), and it is here suggested that the term subsequent structures is used for the latter type.

Both glaciodynamic and subsequent structures form under the influence of gravity, but the former owe their development to the action of glacial flow while the latter do not. Generally, therefore, it is not so difficult to distinguish between them in the field. Judging from published descriptions and interpretations of such structures, there seem to be several convergent types. Marcussen (1973, fig. 12) thus describes flow till structures, which the present author would rather classify as typical glaciodynamic structures, and deformational structures interpreted by Everson, Dreimanis \& Newsome (1977) as having formed under subaquatic conditions strongly recall structures found in Denmark in frontal flow tills and interlayered sandur deposits that were reworked during a further advance and incorporated in the overlying lodgement till. Obviously, more structural studies of such convergent types are urgently needed.

In the search for directional elements it is less vital to distinguish between exodiamict and endiamict structures in the sense of Banham (1975), because both pro- and sub- as well as englacially formed structures can be used as direction indicators.

The comprehensive literature on types of directional elements, their measurement and statistical treatment, cannot be discussed here, but the author would in general recommend the use of three-dimensional plotting procedure (on equal area nets or polar projection nets) instead of histograms and compass rose diagrams, because presented stereographically, the data can better be critically evaluated. The directional elements used in kineto-stratigraphic studies in Denmark are illustrated diagrammatically in fig. 7 , and in fig. 8 the symbols recommended for use in future mapping by the Geological Survey of Denmark are shown.

Discrimination between good, moderate and poor structural indicators of glacial flow or push 


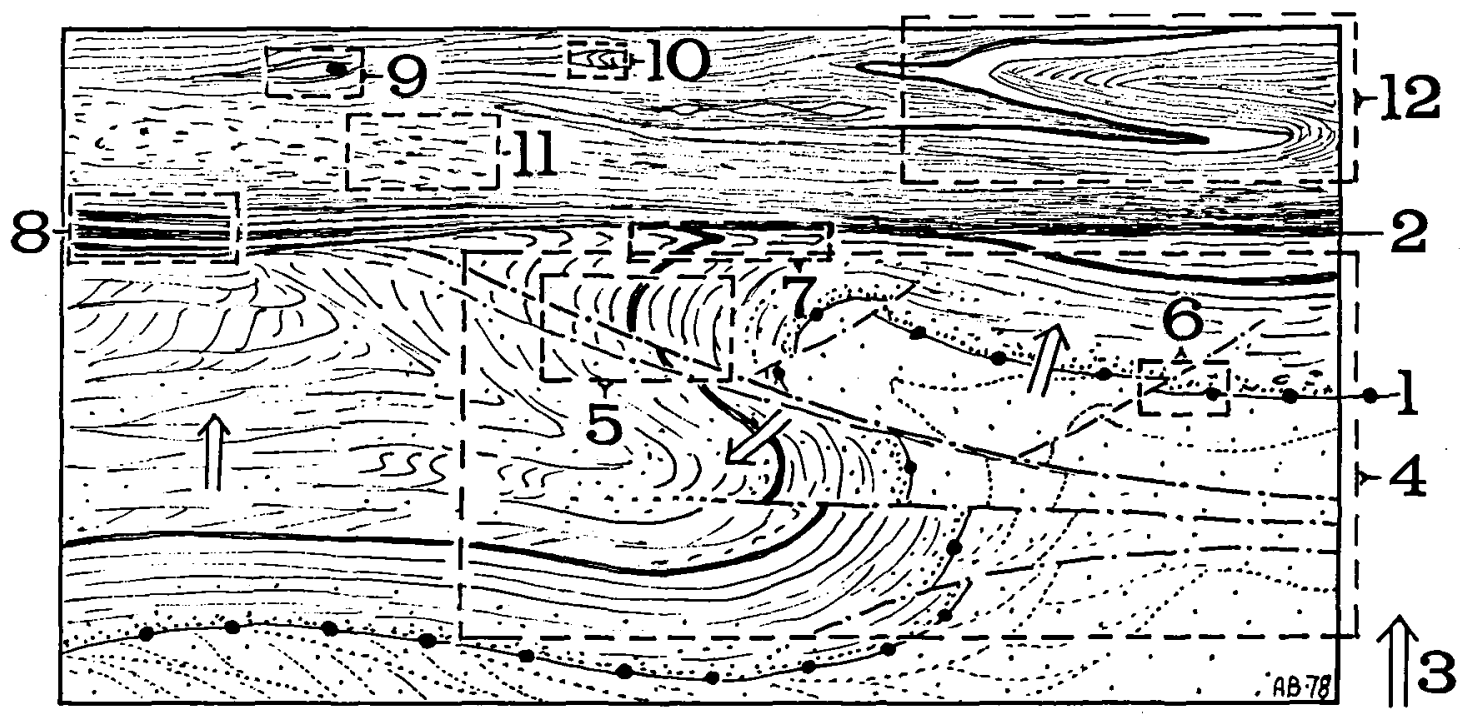

Fig. 7. Diagram showing important types of glacier-induced structures and their relative importance as directional elements (indicated by the size of the stipled frame). - I: boundary between an upper kineto-stratigraphic unit with domainal deformation and subjacent strata with extra-domainal deformation. - 2: base of lodgement till; a possible upper ablation till is not shown. - 3: way-up in glaciofluvial sediments. 4: field of combined glacial-tectonic studies. - 5: overthrusts;

depends not only on the lithologies involved, but also on the temperature conditions which prevailed during the formation of the structures. With this reservation, it can be stated as a generalisation that the larger in amplitude and the more extensively developed a structural type is, the greater is the importance that can be attached to it. Glacial-tectonic disturbances that influence large volumes of rocks are obviously more important indicators than displacements of a few centimetres in a till. When stratified drift showing large-scale crossbedding is folded or sheared, it must be remembered that the initial strike and dip of laminae predetermine the orientation of axes of small folds or drag flexures and cause considerable uncertainity. Where possible, structural readings should be taken preferably on true bedding planes.

An anisotropic till fabric measured at a glacialtectonically undisturbed locality is more significant than several gropus of measurements made in contorted drift where preferred orientations both parallel and perpendicular to the transport direction could be expected (Berthelsen 1975 a, b). In the latter case, construction of fold axes from strike and dip measurements, supplemented with note how they converge in the direction opposite to the ice movement. - 6: conjugate thrusts with opposite sense of movement. - 7: sub-sole drag. In this zone shearing becomes intense. - 8: striations in mylonitic till. - 9: torpedo structure. 10: intrafolial folds of $\mathrm{cm}$-size. - 11: till fabric analyses. - 12: glaciodynamic structures of m-size. - Other structures of less directional value are also shown, but not framed, for example boudinage structures. observations on the way-up of the strata and the Vergenz of the structure, is of more importance. In some till fabric analyses less well defined orientation types are encountered. A type with 'mixed orientation' is characterised by a single symmetry plane that on an equal areas net runs parallel to the transport direction (fig. 8, 4c).

Sandy mylonitic striations close to the sole of a lodgement till are useful indicators and many be measured quickly when dug out from below. With a little more work, the streamlineaxis of what the author (Berthelsen 1976) has called torpedo structures may be determined. In these structures the flow banding bends around equidimensional boulders, and unlike structures formed in response to melt-out compaction, torpedo structures are elongated in the direction of glacial transport (fig 9).

Intrafolial folds in gneissic till (in the sense of Lavrushin 1971) are less reliable as direction indicators since the orientation of their axes is also dependent on the 'initial dip' of the deflected shearplane banding, and the intrafolial structure as such may have been rotated during continued glacial transport after its formation, kilometres away ('upstream') from where it is observed now. 


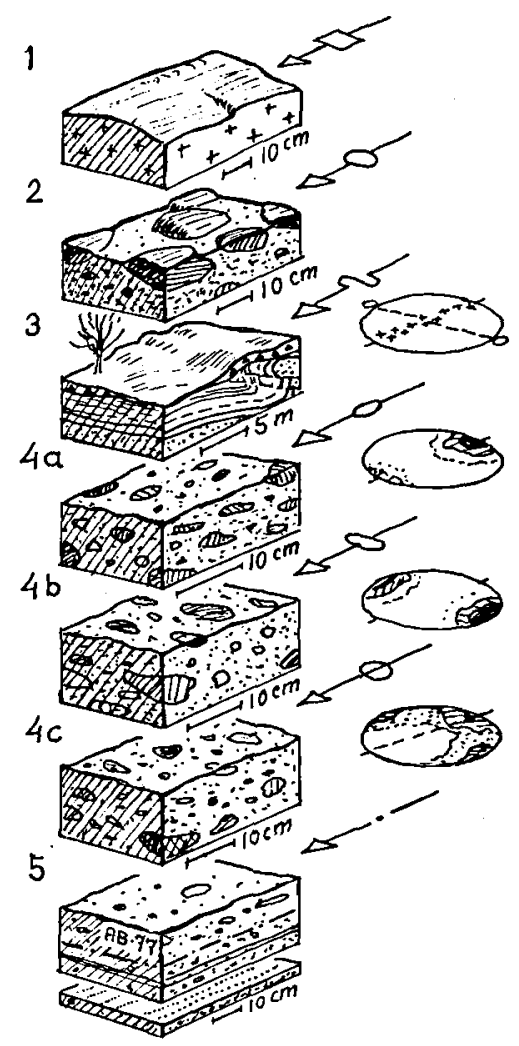

Fig. 8. Directional elements in glacial deposits; redrawn from the author's sketches in Sørensen \& Nielsen (1978). - 1: glacial striae on bedrock. - 2: glacial striae on glacial pavements. 3: "ice-push" determined from study of glacialt-ectonic structures of appropriate size. Structural data are plotted on equal area nets. - 4: till fabric studies. The orientations of the long axis of inequidimensional stones are measured and plotted on equal area polar nets. - a: orientation parallel to transport with a slight plunge opposite to the direction of ice flow. $b$ : orientation perpendicular to transport, where long axis trends are parallel to fold axes. - c: 'mixed orientation', where the majority of the long axes plunge (obliquely) opposite to the movement direction which is indicated by the symmetry plane of the diagram. - 5: striations in mylonitic till soles. In clayey tills, sandy films or coatings show striations parallel to the direction of movement.

The larger, the more open and the less flattened glaciodynamic folds in gneissic tills are, the better is the information they provide.

Glacially induced thrusting usually offers good opportunities for determination of the transport direction, but, as shown in subarea 4 in fig. 7 , thrusts may dip in the direction of transport, and not always against it, and the sense of displacement along a conjugated set of thrusts (see framed sub-area nr. 6 in fig. 7) may be opposite to the

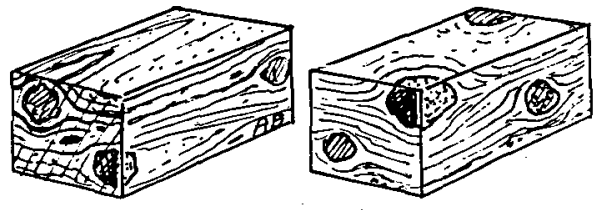

Fig. 9. Torpedo structures (left) and melt-out compaction (right) around larger clasts in glaciodynamically banded till.

general direction of displacement so that one has a form of underthrusting.

So far only those directional elements that are related directly to the dynamics of a moving ice sheet have been considered, i.e. the syngenetic and cogenetic structures of the kineto-stratigraphic till unit in question (sub-areas 5-12 in fig. 7) and the epigenetic structures formed by the same ice sheet (see bottom right part of fig. 7). The primary structures of the stratified drift deposits remain to be considered.

Primary structures in stratified drift (fig. 10) are only related to glacial dynamics in so far, that melt water rarely flows away in a direction opposite to that of the ice movement. Palaeocurrent directions determined in stratified drift should therefore be used with caution when attempting to correlate such deposits to their proper kinetostratigraphic unit. Situations where there is a close correlation between the hydrodynamic and glacial flow directions have been reported from Als (Sjørring $1977 \mathrm{a}$ ), and when larger areas are studied palaeocurrent measurements may give an added perspective to the whole study. In the Randers area, Larsen, Liboriussen \& Willumsen (1972) and Larsen, Jørgensen \& Prisholm (1977) have thus been able to outline a pre-existing Saalean topography from palaeocurrent measurements in Weichselian sandur deposits filling the depressions in this landscape, but not burying it entirely: From the same area, the kinetic pattern of a still younger ledgement till that coats the softened Saalean landscape has been analysed, and it can be seen how little influence the topographic variations exerted on the flow pattern of the transgressing ice which deposited this till.

\section{Weichselian kineto-stratigraphy of southeastern Denmark}

On the basis of the contributions of several researchers a regionally valid kineto-stratigraphic 


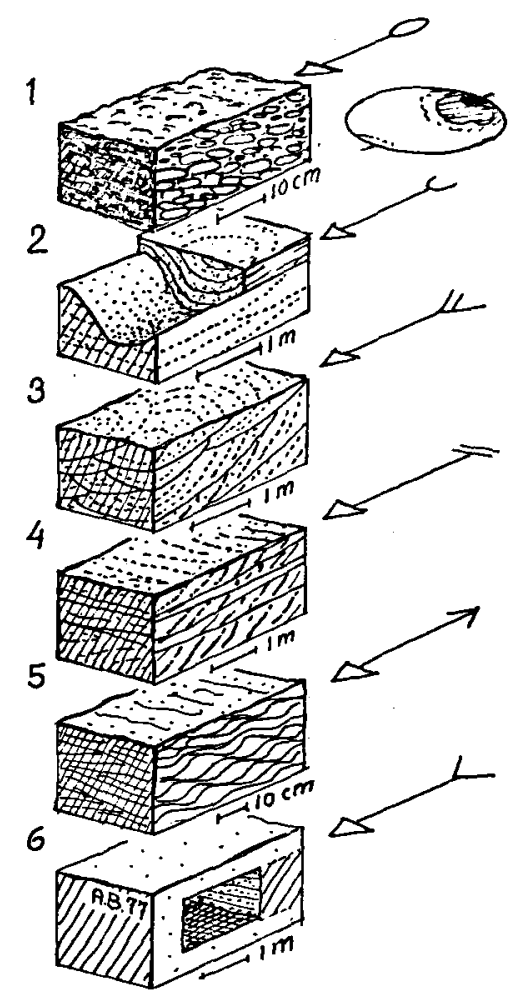

Fig. 10. Sedimentary structures and palaeocurrent measurements; redrawn from the author's sketches in Sørensen \& Nielsen (1978). - 1: pebble imbrication. Flat stones dip upcurrent and either the long or the intermediate axis of the imbricated pebbles plunges upcurrent. Dips are plotted on polar nets. - 2: trough axes of erosion channels are measured directly or constructed for each trough from strike and dip readings on the channel-fill laminae. - 3: trough cross bedding caused by lunate megaripples. If the maximum foreset dip can not be measured directly, a sufficiently large number of foreset laminae are measured and plotted on equal area nets. The symmetry plane in the diagram is parallel to the plaeocurrent. 4: planar cross bedding caused by straight-crested megaripples. Measurement and plotting as for type 3 to which transitions occur. - 5: climbing ripple lamination where false cross bedding dips (more or less) upstream. Foreset laminae are measured. 6: symbol for foreset measurements of unspecified type, but of megaripple size.

classification of the Weichselian glacial deposits of southeastern Denmark can now be made. A total of four main advances and corresponding drifts units are recognised, only three of these were mentioned by Berthelsen (1973). 'Interstadials' where periglacial conditions governed an ice-free or locally dead-ice-covered landscape separated the advances. The interstadial between the second-last and the last main advance apparently included an interval where the climate was mild enough to permit free groundwater circulation and increased geochemical activity (the Asnæs interstadial of Berthelsen (1975 b, p. 3740)). All the main advances are believed to have taken place during the later part of Middle Weichselian (25.000-13.000 BP, cf. Mangerud et al. 1974).

The tills of the two oldest advances, which came respectively from a northerly and a southeasterly direction, apparently never overlapped, but palaeocurrent measurements in stratified drift deposits on northern Samsø and neighbouring islands (Houmark-Nielsen 1976 b) suggest that the advance from the north was older than that from southeast. That from the north is called the Norwegian ice, while that from southeast is referred to as the Old Baltic Advance, fig. 11.

The next main advance came to eastern Denmark from a northeasterly direction but swung to a westerly flow direction before it reached the Main Stationary Line in Jutland (Berthelsen 1973, Larsen et al. 1977). Deposits belonging to the kinetostratigraphic drift unit left by this so-called NEice have also been described by Rasmussen (1973, 1975), Sjørring (1974, 1977 a), Jensen (1977),

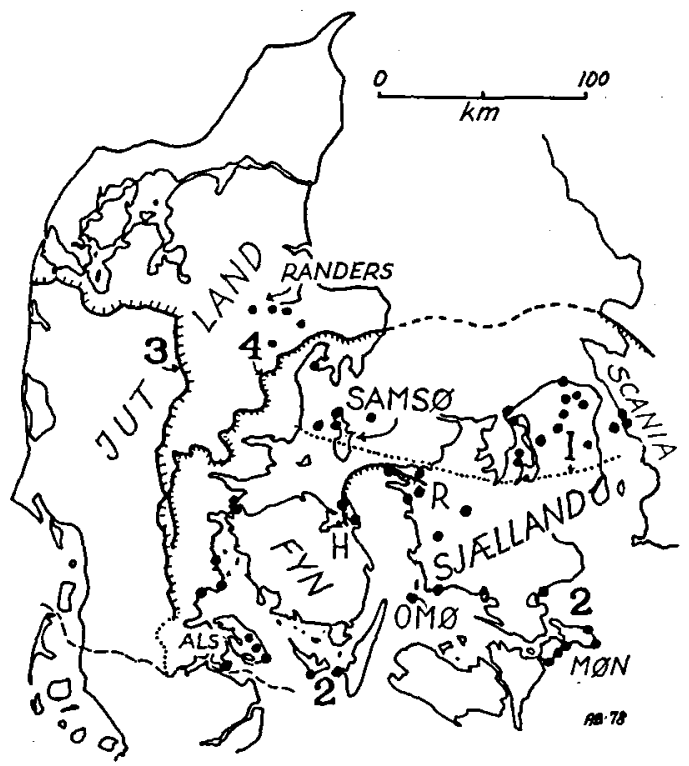

Fig. 11. Sketch map of Denmark. - 1: supposed southern limit of 'Norwegian ice'. - 2: localities with proven 'Old Baltic' deposits. - 3: Main Stationary Line. - 4: Eastjutlandic Ice Border Line. - H-R: Hindsholm-Resnces line. Black dots denote investigated principal localities. 
Berthelsen (1974, 1975 b), Berthelsen et al. (1977), Petersen \& Konradi (1974), Jacobsen (1976), Houmark-Nielsen (1976 a amd b), and Frederiksen (1976) from a number of principal localities covering southeastern Denmark, fig. 11.

The last Weichselian ice sheet came from the south-southeast, via the Baltic, and covered southeastern Denmark east of the East Jutlandic Ice Border Line, and west of the ice border line of the Baltic Ice in Scania (Berthelsen 1973). In the Danish region, this advance is referred to as the Young Baltic advance. As mentioned on p. 31, the Young Baltic Advance made a noteworthy readvance to the Hindsholn-Røsnæs line during its general retreat, fig. 11 .

These results stand in sharp contrast to earlier official opinions (Hansen \& Nielsen, 1960) which only admitted one major Middle Weichselian advance with local readvances during the recession. An possible explanation of this discrepancy may be that in earlier investigations too much emphasis was placed on morphological features, even where these were not necessarily formed during one and the same glacial advance. In Denmark, as in neighbouring regions, recent work has demonstrated that old landforms have survived younger ice transgressions (Berthelsen 1971, 1973, 1975 b, Larsen et al. 1972, Rasmussen 1975, Larsen et al. 1977, Brinkmann 1953, Seifert 1954, Stephan 1971). Attempts to explain the present morphology as a consequence of a single deglaciation process (Marcussen 1977) represent therefore an extreme, simplicistic point of view, that conflicts with published data.

As mentioned above, the ultimate goal of all kineto-stratigraphic work is to establish a detailed stratigraphic column and correlation scheme. In the outline just given of the Weichselian kinetostratigraphy of southeastern Denmark, no formal nomenclature for the regional drift units, nor for their individual sedimentary units, has been used. The task of giving names we consider as belonging to the very last phase of the work. Most probably, the names given to kineto-stratigraphic units should relate to type regions of distribution, and not to provenance as has been the case in our provisional field slang so far. Names relating to regional distribution - not to a single locality but to a region with several principal localities would ease correlation with neighbouring regions, e.g. Scania and northern Germany. However, a postponement of the solution of these delicate questions need not delay, nor be of any hindrance to the completion of current studies of Danish Weichselian drift stratigraphy.

\section{Acknowledgements}

The author does not hesitate to disclose - and acknowledge - that it was his esteemed teacher, Professor Arne Noe-Nygaard, who diverted a young student's facination with the intricacies of glacial geology into a longlasting interest in structural and orogenic geology. Had this not happened, this paper could hardly have been written.

My best thanks also go to my colleagues in the study of Danish kineto-stratigraphy whose spirit of cooporation has meant much for the completion of this paper. Lektor F. Surlyk, Geological Museum of Copenhagen, kindly read the first draft of this paper critically, and lektor T. C. R. Pulvertaft is thanked for suggestions in connection with terminology and improvements in the English language.

\section{Dansk sammendrag}

Fornyede undersøgelser af sidste istid's (Weichsel) aflejringer i det sydøstlige Danmark har vist, at disse præges af uregelmæssige lejringsforhold og så gennemgribende glacialtektoniske forstyrrelser, at en detaljeret stratigrafi ikke kan opstilles ved anvendelse af klassiske metoder alene. Ved en kombination af glacialtektoniske og lithostratigrafiske metoder er dog udviklet en ny type stratigrafi, kineto-stratigrafi, der gør det muligt at angribe Weichsel-aflejringernes komplicerede lejringsforhold og stratigrafi. De nye metoder bygger på grundfjeldstektoniske erfaringer.

Ved kineto-stratifiske undersøgelser lægges vægt på studiet af $\mathrm{i}$ de forskellige stratigrafiske niveauer forekommende retningselementer, d.v.s. de strukturer, der afspejler bevægelsesmønstret (kinematiken) $\mathbf{i}$ de tilsvarende isstrømme. Ved at undersøge spredte hovedlokaliteter, hvor der forekommer aflejringer og isbetingede lagforstyrrelser fra mere end ét fremstød, opstilles regionale kineto-stratigrafiske enheder. Lokalt forekommende glaciale dannelser, hvis stratigrafiske placering ikke aflases direkte pả lokaliteterne, henfores derefter ud fra deres retningselementer til den ene eller anden af de regionale enheder. De forskellige retningselementer (skurestriber pá fast underlag, glaciale brolægninger, stenorienteringer $\mathbf{i}$ moræner og ikke mindst glacialtektoniske og glaciodynamiske strukturer) benyttes pá denne måde næsten ligesom forsteninger anvendes ved biostratigrafiske undersøgelser.

Forudsætningerne for det kineto-stratigrafiske princips anvendelse er, at efter-hinanden-følgende isfremstød er kommet fra forskellige retninger, at hvert fremstød har haft et regelmæssigt bevægelsesbillede, og at glacialtektoniske forstyrrelser kan henføres til det rette dislocerende fremstød. Hvorvidt disse for- 
udsæetninger kan anses for at være opfyldte $\mathrm{i}$ den undersøgte region, SØ-Danmark, diskuteres.

Flere forskeres arbejde efter disse nye principper viser, at Weichsel-aflejringerne i S $\varnothing$-Danmark kan inddeles i fire kinetostratigrafiske enheder - dannet $i$ forbindelse med fire særskilte hovedfremstød ('det norske', 'det gammelbaltiske', 'NØ-isens' og det 'ungbaltiske fremstød'), der alle formodes at have udspillet sig mellem ? 25.000 og $13.000 \mathrm{BP}$. Til slut berøres problemerne $\mathfrak{i}$ forbindelse med de kineto-stratigrafiske enheders formelle navngivning.

\section{References}

Andersen, S. A., 1950: Rågeleje egnens geologi. Meddr. dansk geol. Foren., 11, 543-557.

Andersen, S. A., 1957: Lolland i den sidste istid. Meddr. dansk geol. Foren., 13, 225-235.

Banham, P. H., 1975: Glacialtectonic structures: a general discussion with particular reference to the Contorted drift of Norfolk. In Wright, A. E. \& Moseley, F. (eds.): Ice Ages: Ancient and Modern. Geol. J., Special Issue, 6, 69-94. Seel House Press, Liverpool.

Berthelsen, A., 1960: Structural Studies in the Pre-Cambrian of Western Greenland, II: Geology of Tovqussap Nuna. Meddr. Grenland, 123, 1, 223 p.

Berthelsen, A., 1971: Fotogeologiske og feltgeologiske undersagelser i NV-Sjælland. Dansk geol. Foren., Årsskrift for $1970,64-69$.

Berthelsen, A., 1973: Weichselian ice advance and drift successions in Denmark. Bull. Geol. Inst. Univ. Uppsala, New Ser., 5, 21-29.

Berthelsen, A., 1974: Nogle forekomster af intrusivt moraneler i NØ-Sjælland. Dansk geol. Foren., Ȧrsskrift for 1973, 118-131.

Berthelsen, A., 1975 a: Lærebog for den lille tektoniker. 202 p. Publ. by VARV, c/o Geol. Museum, Copenhagen.

Berthelsen, A., 1975 b: Geologi pá Røsnæes. Ekskursionsfører nr. 3, 78 p. Publ. by VARV, c/o Geol. Museum, Copenhagen.

Berthelsen, A., 1976: Om moræne og glacialstratigrafi. Mimeographed compendium, 28 p., Inst. General Geol., Copenhagen Univ.

Berthelsen, A. \& Henriksen, N., 1975: Geological map of Greenland 1:100000 Ivigtut, 61 V 1 Syd. The orogenic and cratogenic geology of a Precambrian shield area. Meddr. Gronland, 186, 1, $169 \mathrm{p}$.

Berthelsen, A., Konradi, P. \& Petersen, K. S., 1977: Kvartære lagfølger og strukturer i Vestmøns klinter. Dansk geol. Foren., Ársskrift for 1976, 93-99.

Brinkmann, R., 1953: Über die diluvialen Störungen auf Rügen. Geol. Rundsch., 41, 231-241.

Evenson, E. B., Dreimanis, A. \& Newsome, J. W., 1977: Subaquatic flow tills: a new interpretation of the genesis of some laminated till deposits. Boreas, 6, 115-133.

Feyling-Hansen, R. W., Jørgensen, J. A., Knudsen, K. L. \& Andersen, A.-L., 1971: Late Quaternary Foraminifera from Vendsyssel, Denmark and Sandnes, Norway. Bull. geol. Soc. Denmark, 21, (2-3), 67-317.

Frederiksen, J., 1976: Hvad sønderjydske klinter fortæller. Tidssk. VARV, 1976-2. 35-45 (c/o Geol. Museum, Copenhagen).

Gripp, K., 1973: Grundmoräne und Geschiebepflaster. Meyniana, 23, 49-52.

Gry, H., 1940: De istektoniske forhold i molersomrádet. Meddr. Dansk geol. Foren., 9, 5, 586-627.

Hirvas, H., Kujansuu, R. \& Tynni, R., 1976: Till stratigraphy in Northern Finland. In: Easterbrook, D. J. \& Svibrava, V. (editors): Report nr. 3, IGCP Project 73/1/24 (Quaternary glaciations in the Northern Hemisphere), 256-273. Bellingham/Washington/Prague.
Holm, L., 1978: En tungmineral-undersøgelse af kvartære aflejringer (et metodisk studie). Unpubl. cand. thesis, Inst. General Geol., Copenhagen Univ., 99 p.

Hansen, S. \& Nielsen, A. V., 1960: Glacial geology of southern Denmark. Guide to excurs, nos. A44 \& C39. Int. Geol. Congr., XXI Sess., Norden 1960.

Houmark-Nielsen, M., 1976 a: En glacialstratigrafisk oversigt fra Nordsamsø og Tunø. Dansk geol. Foren., Àrsskrift for $1975,11-13$.

Houmark-Nielsen, M., 1976 b: Nordsamsø's istidsnekrolog. Tidssk. VARV, 1976-3, 89-96 (c/o Geol. Museum, Copenhagen).

Jacobsen, E. M., 1976: En morænestratigrafisk undersøgelse af klinterne på Omø. Dansk geol. Foren., Ȧrsskrift for $1975,15-17$.

Jensen, V., 1977: St. Karlsminde klint, materialer og strukturer. Dansk geol. Foren., Ȧrsskrift for 1976, 47-55.

Jessen, A., 1930: Klinten ved Halkhoved. Danm. geol. Unders., IV. Rakke, Nr. 2, $26 \mathrm{p}$.

Jessen, A., 1931: Lønstrup Klint. Danm. geol. Unders., II. Række, Nr. 49, 142 p.

Konradi, P. B., 1973: Foraminiferas in some Danish glacial deposits. Bull. Geol. Inst. Uppsala, New Ser., 5, 173-175.

Konradi, P. B., 1976: Foraminifera in Eemian deposits at Stensigmose, Southern Jutland. Danm. geol. Unsers., række 2, nr. 105, 57 p.

Knudsen, K. L. \& Feyling-Hansen, R. W., 1976: Ergebnisse der Foraminiferenanalyse zur Quartărstratigraphi in Skandinavien. Eiszeitalter $u$. Gegenwart, 27, 82-92.

Konigsson, L.-K. \& Linde, L. A., 1977: Glaciotectonically disturbed sediments at Ronnerum on the island of Oland. Geol. Foren. Stockh. Forh., 99, 68-72.

Larsen, G., Liboriussen, J. \& Villumsen, A., 1972: Kvartærgeologiske undersøgelser pá kortbladet Randers. Dansk geol. Foren., Ársskrift for 1971, 27-40.

Larsen, G., Jørgensen, F. H. \& Prisholm, S., 1977: The stratigraphy, structure and origin of glacial deposits in the Randers area, eastern Jutland. Danm. geol. Unders., række 2, nr. $111.36 \mathrm{p}$.

Lavrushin, Y. A., 1971: Dynamische Fazies und Subfazies der Grundmoräne. Z. Angew, Geol., 17, 337-343.

Lundqvist, J., 1975: Outline of the Weichsel Glacial in Sweden. Geol. Fören. Stockh. Forh., 96, 327-339.

Mangerud, J., Andersen, S. T., Berglund, B. E. \& Donner, J., 1974: Quaternary stratigraphy of Norden, a proposal for terminology and classification. Boreas, 3, 109-128.

Marcussen, I., 1973: Studies on flow till in Denmark. Boreas, 2, 213-231.

Marcussen, I., 1977: Deglaciation landscapes formed during the wasting of the late Middle Weichselian ice sheet in Denmark. Danm. geol. Unders., række 2. nr. 110, 72 p.

Petersen, K. S., 1973: Tills in dislocated drift deposits on the Røsnaes peninsula, northwestern Sjaelland, Denmark. Bull. Geol. Inst. Uppsala, New Ser., 5, 41-49.

Petersen, K. S., 1974: Geologisk rekognoscering fra Rugen til Angel. Dansk geol. Foren., Ảrsskrift for 1973, 57-61.

Petersen, K. S., 1978: Applications of glaciotectonic analyses in geological mapping of Denmark. Danm. geol. Unders., Àrbog 1977.

Petersen, K. S. \& Buch, A., 1974: Dislocated tills with Paleogene and Pleistocene marine beds. Tectonics, lithology, macro- and microfossils. Danm. geol. Unders., Àrbog 1973, 63-91.

Petersen, K. S. \& Konradi, P. B., 1974: Lithologiske og palæontologiske beskrivelser af profiler i kvartæret pa Sjælland. Dansk geol. Foren., Ȧrsskrift for 1973, 47-56.

Rasmussen, L. A., 1973: The Quaternary stratigraphy and dislocations on Ven. Bull. Geol. Inst. Uppsala, New Ser., 5, 37-39. 
Rasmussen, L. Ȧ., 1974: Om morænestratigrafi i det nordlige Øresundsomráde. Dansk geol. Foren., Ảrsskrift for 1973, 132-139.

Rasmussen, L. A., 1975: Kineto-stratigraphic glacial drift units on Hindsholm, Denmark. Boreas, 4, 209-217.

Seifert, G., 1954: Das mikroskopische Korngefüge des Geschiebemergels als Abbild der Eisbewegung zugleich des Eisabbaues in Fehmarn, Ostwagrien und dem Dänischen Wohld. Meyniana, 2, 124-190.

Sjørring, S., 1974: Klinterne ved Hundested. Dansk geol. Foren., Ảrsskrift for 1973, 108-117.

Sjørring, S., 1977 a: The glacial stratigraphy of the island Als, southern Denmark. Z. Geomorph., N.F., Suppl.-Bd. 1-11.

Sjørring, S., 1977 b: Glacialtektonik og istidsgeologi. Dansk Natur - Dansk Skole, Ȧrsskrift for 1977, 31-44, Copenhagen.

Sjørring, S., 1978: Glazialtektonik und Glazialstratigraphie. Einige Beispiele aus Dănemark. Eiszeitalter $u$. Gegenwart, 28, 119-125.

Stephan, H.-J., 1971: Glazialgeologische Untersuchungen im Raum Heiligenhafen (Ostholstein). Meyniana, 21, 67-86.

Stockmarr, J., 1978: Den prækvartære overflade ved Juelsminde. Danm. geol. Unders., Ȧrbog 1976, 49-52.

Sorensen, H. \& Nielsen, A. V. (editors), 1978: The geological Mapping of Denmark. The present state of the mapping proposals for the future mapping. Report prepared by a working group. Danm. geol. Unders., Serie A, Nr. 2, 79 p. (In Danish with English summary and conclusions). 